\title{
Cytokine gene expression during postnatal small intestinal development: regulation by glucocorticoids
}

\begin{abstract}
C Schaeffer, M Diab-Assef, M Plateroti, F Laurent-Huck, J M Reimund, M Kedinger, C Foltzer-Jourdainne
\end{abstract}

in this regulation in parallel with maturation of the gut mucosa at weaning. (Gut 2000;47:192-199)

Keywords: small intestine; weaning; maturation; fibroblasts; cytokines

In the intestinal mucosa, a wide variety of cytokines are produced locally by the epithelium, and by the fibroblasts and immune cells present in the lamina propria; their controlled expression is essential for the homeostasis of the tissue during development as well as in the adult organ. ${ }^{1-3}$ Subepithelial myofibroblasts have been shown to play a fundamental role in epithelial differentiation via epithelialmesenchymal cell interactions during both fetal and adult life..$^{4-6}$ In cocultures, they mediate epithelial differentiation on treatment with glucocorticoids (GC) and retinoic acid ${ }^{7}$; they express morphogenetic, growth, and differentiating factors such as epimorphin, hepatocyte growth and/or scatter factor ( $\mathrm{HGF} / \mathrm{SF})$, and transforming growth factor $\beta 1$ (TGF- $\beta 1$ ) which may be mediators in the cross talk with epithelial cells. ${ }^{9-11}$ Sporadic data are in favour of a modulatory influence of cytokines on intestinal epithelial cell behaviour. The role of fibroblast derived TGF- $\beta 1$ has been emphasised in cocultures in which T84 cells differentiate and acquire an enterocyte-like phenotype ${ }^{12}$; also, both TGF- $\beta 1$ and transforming growth factor $\beta 2$ (TGF- $\beta 2$ ) inhibit epithelial cell growth. ${ }^{13}{ }^{14}$ Transforming growth factor $\alpha$ (TGF- $\alpha$ ) is expressed in the small intestine at weaning ${ }^{15-17}$ and potentially plays a role in rat intestinal maturation. ${ }^{18} 19$ In addition, this cytokine is produced by IEC 6 cells and stimulates their proliferation; TGF- $\alpha$ may represent the main growth promoting stimulus of the intestinal epithelium counterbalanced by the inhibitory effect of TGF- $\beta 1{ }^{20}$ Similarly, the mucosal immune system appears to be implicated in epithelial maturation at weaning when a peak of physiological inflammation occurs in the mucosa. $\mathrm{T}$ cell activation promotes epithelial growth $^{21}$ and inversely, cyclosporin (which increases TGF- $\beta 1$ synthesis and secretion by $\mathrm{T}$ lymphocytes ${ }^{22}$ ) delays intestinal maturation. ${ }^{23}$

Abbreviations used in this paper: GC, glucocorticoids; SI, sucrase-isomaltase; TGF, transforming growth factor; TNF- $\alpha$, tumour necrosis factor $\alpha$; IL- $1 \beta$, interleukin $1 \beta ; \mathrm{HC}$, hydrocortisone; RT-PCR, reverse transcription-polymerase chain reaction; EGF, epidermal growth factor; DTT, dithiothreitol; SSC, standard saline citrate. 
Finally, tumour necrosis factor $\alpha(\mathrm{TNF}-\alpha)$ and interleukin $1 \beta$ (IL-1 $\beta$ ), primarily known as immunoregulatory cytokines mediating normal or pathological inflammatory responses in the intestine, exert multiple biological activities including growth, differentiation, and cellular functions. ${ }^{24-26}$

On the basis of the above information, the aim of our study was to examine the role of mucosal inflammatory cytokines and/or growth factors (TGF- $\beta 1$, TGF- $\beta 2$, TNF- $\alpha$, IL- $1 \beta$, $\mathrm{TGF}-\alpha$ ) on the maturation of the epithelium at weaning. For this purpose we analysed (i) the developmental expression pattern of cytokines in the small intestine along the proximo-distal axis and (ii) the potential correlation between cytokine expression and developmental onset of sucrase-isomaltase (SI) expression around weaning or its precocious induction by an injection of GC. Regulation of cytokine expression by GC was also studied in vitro in subepithelial myofibroblast cell lines.

\section{Materials and methods}

ANIMALS

Newborn Wistar rats were from our own breeding colony. Pregnant rats, individually housed in a lighting cycled, temperature controlled, well ventilated room were given water and standard food at libitum. Pups were left with their mothers until complete weaning and then fed a complete diet at libitum.

The developmental study was performed on pups 14, 18, 21, and 60 days after birth. The small intestine was removed and divided into duodenum (from the pylorus to the ligament of Treitz), proximal jejunum (proximal quarter of the remaining small intestine), and distal ileum (distal quarter). The mucosa was scrapped and immediately frozen in liquid nitrogen until total RNA extraction.

HC TREATMENT

One litter of 11 day old pups was separated into two groups. One group was injected subcutaneously with hydrocortisone (HC; $50 \mu \mathrm{g} / \mathrm{g}$ body weight; Sigma, France) and the control group received the same volume of vehicle (NaCl 9\%, $25 \mu \mathrm{l} / \mathrm{g}$ ). Pups were killed at 12 days; the proximal jejunum was scrapped and frozen for subsequent analysis.
CELL CULTURE

Four clonal cell lines derived from eight day old rat intestinal lamina propria (proximal jejunum (MIC 101-1 and 101-2) and distal ileum (MIC 216 and $\left.219^{10}\right)$ ) were used. Cells were cultured in Dulbecco's modified Eagle medium supplemented with $10 \%$ fetal calf serum, $0.25 \mathrm{U} / \mathrm{ml}$ insulin, $10 \mu \mathrm{g} / \mathrm{ml}$ transferrin, $20 \mathrm{ng} / \mathrm{ml}$ epidermal growth factor (EGF), and $40 \mu \mathrm{g} / \mathrm{ml}$ gentamycin. In experimental conditions, $8 \times 10^{-7} \mathrm{M}$ dexamethasone (DX) (Sigma) was added for two days to the basic culture medium. Cells were frozen at $-80^{\circ} \mathrm{C}$ until RNA extraction.

\section{RT-PCR ANALYSIS}

Tissues and cultured cells were homogenised and RNA was isolated using TRIzol reagent (Gibco/PRL) according to the manufacturer's instructions. Precipitated nucleic acids were washed in $75 \%$ ethanol, dried, and resuspended in water. Single stranded cDNAs were synthesised for 60 minutes at $42^{\circ} \mathrm{C}$ using $6 \mu \mathrm{g}$ of RNA, $10 \mathrm{U}$ of avian myeloblastosis reverse transcriptase (Promega, France), oligo $(\mathrm{dT})_{17}$ primer (50 pM, Eurogentec, Belgium), $0.2 \mathrm{mM}$ each of deoxynucleotide triphosphate (dATP, dGTP, dCTP, and dTTP; Promega, France), in $50 \mu \mathrm{l}$ of reaction buffer $(50 \mathrm{mM}$ Tris $\mathrm{HCl}, \mathrm{pH} 8.3,50 \mathrm{mM} \mathrm{KCl}, 10 \mathrm{mM} \mathrm{MgCl}{ }_{2}$, $0.5 \mathrm{mM}$ spermidine, $10 \mathrm{mM}$ dithiothreitol (DTT)). cDNA was then amplified by polymerase chain reaction (PCR) using specific oligonucleotide primers (table 1) designed to detect cytokines (TGF- $\beta 1$ and $\beta 2, \mathrm{TGF}-\alpha$, TNF- $\alpha$, IL- $1 \beta$ ), a marker of intestinal differentiation (SI), and control ( $\beta$-actin and a ribosomal phosphoprotein) cDNAs. The PCR reactions were carried out in $100 \mu \mathrm{l}$ of $75 \mathrm{mM}$ Tris $\mathrm{HCl}, \mathrm{pH} 9,20 \mathrm{mM}\left(\mathrm{NH}_{4}\right)_{2} \mathrm{SO}_{4}, 0.01 \%$ Tween 20, $1 \mathrm{mM} \mathrm{MgCl}_{2}, 0.2 \mathrm{mM}$ of each dNTP, $0.5 \mathrm{U}$ of Dynazyme DNA polymerase (Finnzymes Oy, Riihitontuntie, Finland), $50 \mathrm{pM}$ of each primer, and $2 \mu \mathrm{l}$ of the cDNA mixture. cDNAs were amplified for a determined number of cycles (table 1) as follows: denaturation for 45 seconds at $94^{\circ} \mathrm{C}\left(94^{\circ} \mathrm{C}\right.$ for one minute in the initial cycle), annealing at 50 or $60^{\circ} \mathrm{C}$ for 45 seconds, and elongation at $72^{\circ} \mathrm{C}$ for 45 seconds, followed by a final five minutes at $72^{\circ} \mathrm{C}$. For every oligonucleotide pair and for every RNA species, a preliminary analysis was

Table 1 Synthetic oligonucleotides and experimental conditions used in reverse transcription-polymerase chain reaction (RT-PCR) analysis

\begin{tabular}{|c|c|c|c|c|c|}
\hline Gene & Position & $\begin{array}{l}\text { Fragment } \\
\text { size }(b p)\end{array}$ & Sequence & $\begin{array}{l}\text { Cycling } \\
\text { number }\end{array}$ & $\begin{array}{l}\text { Hybridisation } \\
\left({ }^{\circ} \mathrm{C}\right)\end{array}$ \\
\hline$\beta$-actin & $\begin{array}{l}326-351 \\
733-706\end{array}$ & 380 & 5'-ATATCGCTGCGCTCGTCGTCGACAA & 28 & 50 \\
\hline $\begin{array}{l}\text { Ribosomal } \\
\text { phosphoprotein }\end{array}$ & $\begin{array}{l}340-360 \\
847-828\end{array}$ & 486 & $\begin{array}{l}\text { 5'-GTTCACCAAGGAGGACCTCA } \\
\text { 3'-AGACACCTCTGCCTAATGTG }\end{array}$ & $23-25$ & 50 \\
\hline TGF- $\beta 1$ & $\begin{array}{l}731-752 \\
1415-1392\end{array}$ & 661 & $\begin{array}{l}\text { 5'-GAAGTCACCCGCGTGCTAATGG } \\
\text { 3'-GGATGTAAACCTCGGACCTGTGTG }\end{array}$ & $30-32$ & 50 \\
\hline TGF- $\beta 2$ & $\begin{array}{l}1-22 \\
214-192\end{array}$ & 192 & $\begin{array}{l}\text { 5'-TTCGCAGGTATCGATGGCACCT } \\
\text { 3'-CGTCGTATTAACGACGGAAGCGG }\end{array}$ & $30-40$ & 50 \\
\hline TNF- $\alpha$ & $\begin{array}{l}3033-3055 \\
3178-3155\end{array}$ & 122 & $\begin{array}{l}\text { 5'-TTCTGTGAAAACGGAGCTAAAC } \\
\text { 3'-TTTATTACGACTAAACCACTGGT }\end{array}$ & $35-40$ & 50 \\
\hline TGF- $\alpha$ & $\begin{array}{l}3538-3557 \\
3930-3911\end{array}$ & 373 & $\begin{array}{l}\text { 5'-ATGTTGTTCCCTGCAAGTCC } \\
\text { 3'-ACTATGGAGAGGGGTCGCTT }\end{array}$ & $25-30$ & 50 \\
\hline IL-1 $\beta$ & $\begin{array}{l}823-843 \\
1011-992\end{array}$ & 169 & $\begin{array}{l}\text { 5'-GCAATGGTCGGGACATAGTT } \\
\text { 3'-GAATGTGCCACGGTTTTCTT }\end{array}$ & 33 & 50 \\
\hline SI & $\begin{array}{l}321-344 \\
776-753\end{array}$ & 432 & $\begin{array}{l}\text { 5'-TGGGATGATGGCCAATCTAAAGAT } \\
\text { 3'-ATAGGGATTGTGTTCTGGAGGAAA }\end{array}$ & 32 & 60 \\
\hline
\end{tabular}


A

Age (days):

Duodenum

$14-182160$

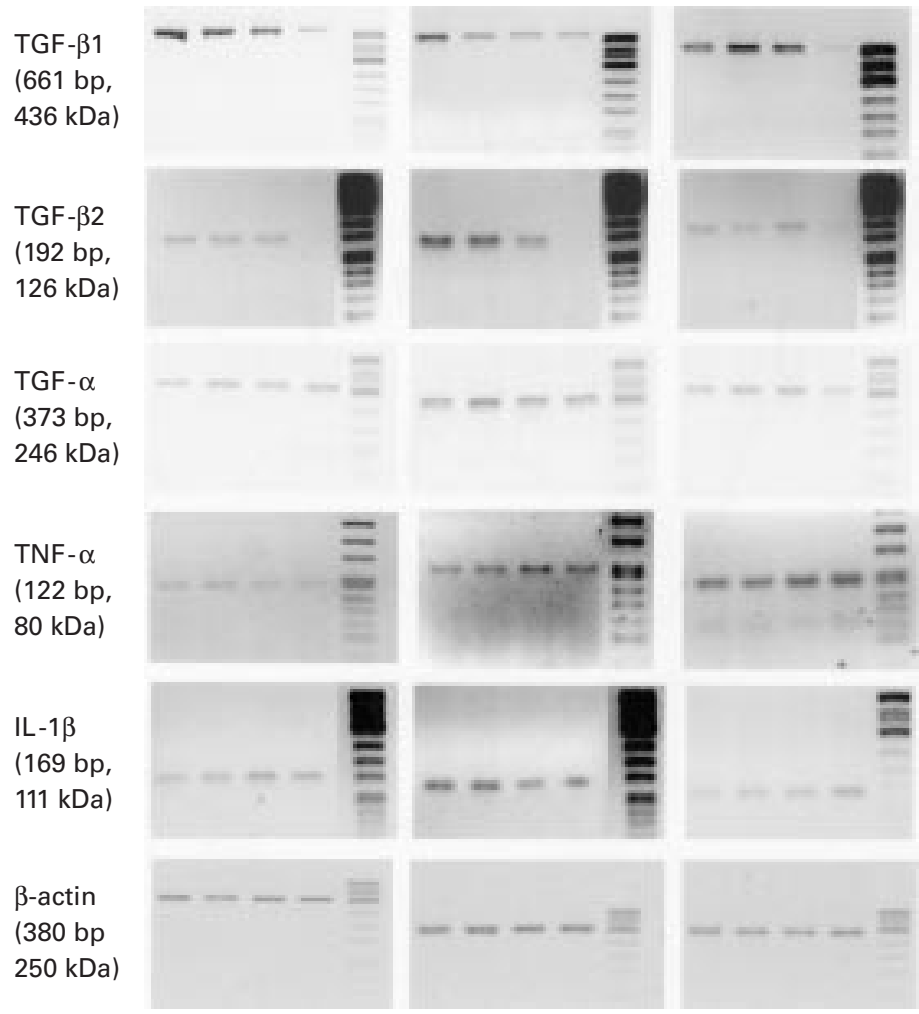

B

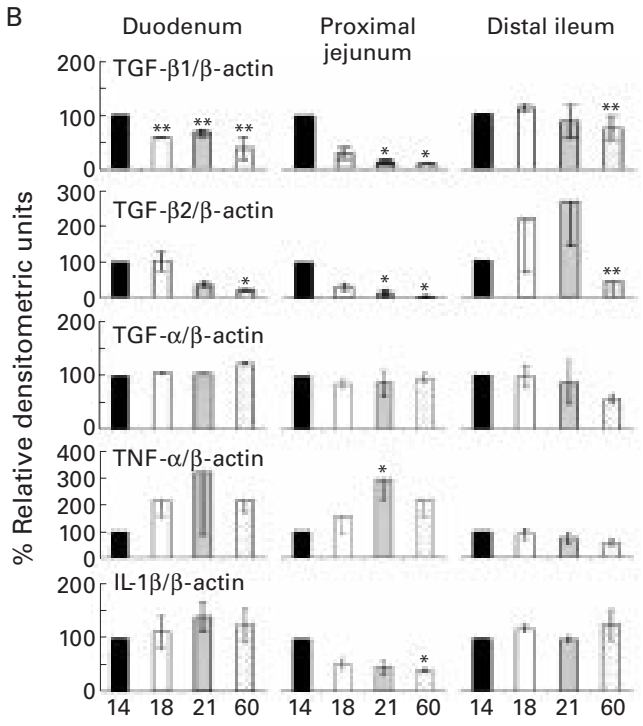

Figure 1 Representative illustration of the developmental pattern of cytokine expression in the small intestinal mucosa from suckling rats. (A) RT-PCR analysis of transforming growth factor $\beta 1$ and $\beta 2$ (TGF- $\beta 1, T G F-\beta 2)$, transforming growth factor a (TGF- $\alpha)$, tumour necrosis factor a (TNF-a), and interleukin $1 \beta(I L-1 \beta)$ in the duodenum, proximal jejunum, and distal ileum of 14,18,21, and 60 day old rats. (B) Densitometric analysis of the specific bands normalised to the corresponding values of $\beta$-actin $m R N A$ used as internal control; mean (SEM) of values (expressed as percentages of the relative intensity of the bands at 14 days) obtained from three independent experiments. Significant differences compared with values obtained in 14 day old suckling rats (unpaired t test): ${ }_{p}<0.05,{ }^{*} p<0.01$.

conducted to define the appropriate range of cycles consistent with an exponential increase in the amount of the DNA product. After electrophoresis on 3\% agarose gels, the intensity of the ethidium bromide luminescence was evaluated using the Molecular Analyst/PC image analysis software (Bio-Rad Laboratories, USA). Results were expressed as relative densitometric units, related to $\beta$-actin or phosphoribosomal protein, and statistical differences determined by Student's $t$ test. Reverse transcription-polymerase chain reaction (RTPCR) fragments were inserted into the pGEM-T vector (Promega) and nucleotide sequences determined using the T7 Sequencing kit (Pharmacia, Orsay, France) to confirm the identity of the amplified cDNA fragments. Control PCR were performed by using RNA samples that were not subjected to RT; no amplified fragment corresponding to genomic DNA was detected under these conditions.

\section{IN SITU HYBRIDISATION ANALYSES}

The onset of SI mRNA expression in the proximal jejunum was analysed using in situ hybridisation techniques described previously. ${ }^{27}{ }^{28}$ The proximal jejunum was removed from pups on postnatal days $11,16,18,21$, and 60 , washed in $\mathrm{NaCl} 0.9 \%$ containing ribonuclease inhibitor $(0.8 \mathrm{u} / \mathrm{ml}$; Promega) and fixed in $4 \%$ paraformaldehyde in $0.1 \mathrm{M}$ phosphate buffered saline ( $\mathrm{pH}$ 7.4) for two hours. Tissues were then embedded in OCT, frozen in isopentane cooled in liquid nitrogen, and stored at $-80^{\circ} \mathrm{C}$. Cryostat sections $(12 \mu \mathrm{m})$ were thaw mounted on 3-aminopropylethoxysilane coated slides and stored at $-80^{\circ} \mathrm{C}$.

RNA probes were prepared from a rat sucrase cDNA (GC $4.5 ; 3.0 \mathrm{~kb}$, a gift from $\mathrm{Dr}$ $S$ Henning) cloned into a pBluescript SK +/plasmid. ${ }^{29}$ The transcription vector was linearised with the appropriate restriction enzyme (Sma I or Sal I). Sense and antisense RNA probes were synthesised using T3 and T7 polymerases, respectively, and ${ }^{35} \mathrm{~S}$ labelled UTP (Amersham, France) under the following conditions: $10 \mathrm{mM} \mathrm{NaCl}$; $40 \mathrm{mM}$ Tris $\mathrm{HCl}, \mathrm{pH}$ 7.5; $6 \mathrm{mM} \mathrm{MgCl}_{2} ; 2 \mathrm{mM}$ spermidine; $5 \mathrm{mM}$ DTT; $0.05 \mathrm{mg} / \mathrm{ml}$ bovine serum albumin; 0.5 mM ATP, CTP, and GTP; 0.01 mM UTP; 100 $\mu \mathrm{Ci}\left[{ }^{35} \mathrm{~S}\right] \mathrm{UTP}(1300 \mathrm{Ci} / \mathrm{mmol}) ; 1 \mathrm{U} / \mu \mathrm{l} \mathrm{RNA}-$ sin; $1 \mathrm{U} / \mu \mathrm{lT} 7$ or T3 RNA polymerase, in a final volume of $20 \mu \mathrm{l}$. The cRNA probes were subjected to partial alkaline hydrolysis at $60^{\circ} \mathrm{C}$ to a final length of about 150 nucleotides. The specific activity of the probes was $5-10 \times 10^{8}$ $\mathrm{cpm} / \mu \mathrm{g}$.

Prehybridisation treatment consisted of acetylation of the sections for 10 minutes in $0.25 \%$ acetic anhydride to reduce non-specific binding with ${ }^{35} \mathrm{~S}$ labelled probes. In some cases, for specificity tests, RNAse $(250 \mu \mathrm{g} / \mathrm{ml})$ pretreatment was performed before acetylation in $2 \times$ SSC (standard saline citrate), $10 \mathrm{mM}$ Tris, $\mathrm{pH} 7.5$, and $1 \mathrm{mM}$ EDTA for 60 minutes at $37^{\circ} \mathrm{C}$, followed by three washes in $2 \times \mathrm{SSC}$ for 10 minutes at room temperature. Hybridisation was performed at $55^{\circ} \mathrm{C}$ for 16 hours in $50 \%$ deionised formamide, $10 \mathrm{mM} \mathrm{DTT}$, $1 \times$ Denhardt's, $1 \mathrm{mM}$ EDTA, $10 \mathrm{mM}$ Tris $\mathrm{HCl}$, $\mathrm{pH} 7.5,0.6 \mathrm{M} \mathrm{NaCl}, 500 \mu \mathrm{g} / \mathrm{ml}$ yeast tRNA, $250 \mu \mathrm{g} / \mathrm{ml}$ denatured herring sperm DNA, $10 \%$ dextran sulphate, and $0.3 \mu \mathrm{g} / \mathrm{ml}$ ${ }^{35} \mathrm{~S}$ labelled RNA probe $\left(15 \times 10^{5} \mathrm{cpm} / 30 \mu \mathrm{l}\right.$ per slide). Washes consisted of the following steps: twice in $2 \times \mathrm{SSC}$ for 10 minutes at room 

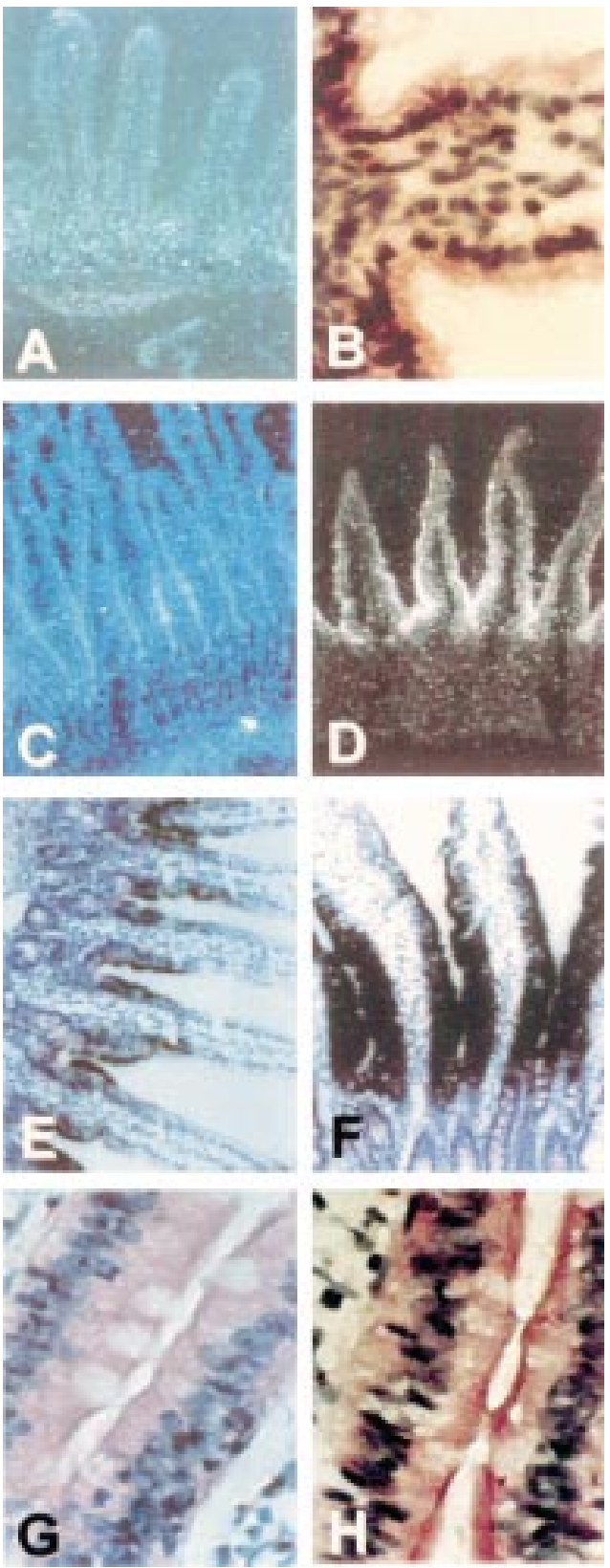

Figure 2 Developmental pattern of sucrase-isomaltase (SI) $m R N A$ expression. In situ hybridisation was performed on sections of the proximal jejunum using an SI antisense $c R N A$ probe as described in materials and methods. Dark field $(A, C, D)$ and bright field

illuminations $(B, E-H)$ of intestinal sections from $11(A$, $B), 16(C), 18(D), 21(E)$, and $60(F-H)$ day old rats. Controls: hybridisation with a sense probe $(G)$ or treatment of the section with RNAse before hybridisation $(H)$.

Magnifications: $A, C-F \times 50 ; B, G, H, \times 250$.

temperature, once in NTE $(0.5 \mathrm{M} \mathrm{NaCl}, 10$ $\mathrm{mM}$ Tris $\mathrm{HCl}, \mathrm{pH} 7.5,5 \mathrm{mM}$ EDTA, $\mathrm{pH}$ 8) for five minutes at $37^{\circ} \mathrm{C}$, once in NTE and RNAse $(10 \mu \mathrm{g} / \mathrm{ml})$ for 15 minutes at $37^{\circ} \mathrm{C}$, three times in NTE for five minutes at room temperature, twice in $1 \times \mathrm{SSC}$ for five minutes at room temperature, once in $0.1 \times \mathrm{SSC}$ for five minutes at $60^{\circ} \mathrm{C}$, once in $0.1 \times \mathrm{SSC}$ for 30 minutes at $60^{\circ} \mathrm{C}$, and twice in $2 \times \mathrm{SSC}$ for five minutes at room temperature. The sections were then passed through graded ethanols containing $0.3 \mathrm{M}$ ammonium acetate and air dried. Slides were then dipped in LM1 emulsion (Amer- sham, France), exposed at $4^{\circ} \mathrm{C}$ in a light tight box for two weeks and developed using Kodak D19 developer and counterstained with haematoxylin and eosin. Data were analysed by observation under a light and dark field photomicroscope.

\section{Results}

DEVELOPMENTAL EXPRESSION OF TGF- $\beta 1$ AND

TGF- $\beta 2$, TGF- $\alpha$, TNF- $\alpha$, AND IL-1B

To evaluate the possible role of the cytokines in the functional development of the small intestine during postnatal life, we analysed their expression using a semiquantitative RTPCR technique during the period of weaning compared with the mature organ (60 days). The results (fig 1) showed that all growth factors and proinflammatory cytokines were expressed in the small intestinal mucosa. The high number of cycles needed to detect TNF- $\alpha$ and TGF- $\beta 2$ mRNA (table 1 ) indicated low expression of these transcripts. No significant variations in TGF- $\alpha$ mRNA were observed as a function of the developmental stage in each intestinal segment. In contrast, the amounts of TGF- $\beta 1$ and TGF- $\beta 2$ mRNAs decreased sharply during the third week of life (18-21 days) in the duodenum and proximal jejunum; in the ileum a significant decrease was obvious only at the adult stage. It is noteworthy that TGF- $\beta 2$ was only weakly expressed in the adult small intestinal mucosa. For TNF- $\alpha$, a clearcut and progressive increase during the third week of life occurred in the proximal jejunum; concomitantly, IL-1 $\beta$ expression decreased in this segment. Only small variations in these two transcripts were observed in the duodenum and distal ileum. In general, expression of the various cytokines was highest in the proximal jejunum and at the youngest developmental stage studied. Expression of the cytokines in the colon was lower than that in the small intestinal mucosa (not shown).

\section{DEVELOPMENTAL ONSET OF SI mRNA IN THE} PROXIMAL JEJUNUM

In rodents, the last step of small intestinal functional maturation is characterised, among other changes, by an overall increase in the digestive enzyme activities and the onset of SI expression around weaning. To correlate the expression pattern of the cytokines to intestinal maturation, we studied the appearance of SI mRNA in the proximal jejunum at various postnatal developmental stages using in situ hybridisation (fig 2). No hybrid signal was detected in 11 day old pups (fig 2A, B). From day 16 and during the third week, SI mRNA was detected and restricted to the cells from the lower third of the villi (fig 2C-E). Concomitant with an increase in the intensity of the staining, the grains became progressively concentrated to the apical part of the enterocyte (fig $2 \mathrm{D}, \mathrm{E}$ ). In the adult, the intensity of staining was further increased (fig $2 F$ ), and the strand-like apical accumulation was present along at least two thirds of the villus height. The specificity of the SI mRNA signal was confirmed using a sense strand RNA in all 


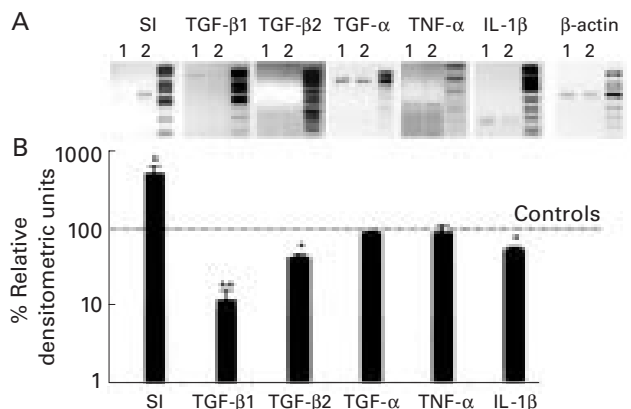

Figure 3 Effects of hydrocortisone (HC), injected in 11 day old pups, on sucrase-isomaltase (SI) induction and cytokine expression. (A) Representative RT-PCR assays detecting SI, transforming growth factor $\beta 1$ and $\beta 2$ $(T G F-\beta 1, T G F-\beta 2)$, transforming growth factor $\alpha$ $(T G F-\alpha)$, tumour necrosis factor a (TNF-a), interleukin $1 \beta(I L-1 \beta)$, and $\beta$-actin $m R N A$ s at postnatal day 12 : lanes 1 , control; lanes 2 , treated animals. (B) Densitometric analysis of $S I, T G F-\beta 1, T G F-\beta 2, T G F-\alpha, T N F-\alpha$, and $I L-1 \beta$ bands normalised to values of $\beta$-actin as internal control from three independent experiments. Results are illustrated in the HC treated tissues as percentages of control values. ${ }^{\star} p<0.05,{ }^{\star \star}{ }_{p}<0.01$, significant differences between HC treated and control animals (unpaired t test).

postnatal stages studied (fig $2 \mathrm{G}$ ). In addition, no labelling was detected on slides pretreated with RNAse (fig $2 \mathrm{H}$ ).

EFFECT OF HC INJECTION ON SI INDUCTION AND CYTOKINE EXPRESSION

To further analyse the potential correlation between cytokine variations and intestinal maturation, and to evaluate hormonal regulation of mucosal cytokines, precocious maturation was induced in preweaning pups by injection of HC. Expression of SI, TGF- $\beta 1$ and $\beta 2$, TGF- $\alpha$, TNF- $\alpha$, and IL- $1 \beta$ was evaluated by RT-PCR in the proximal jejunum (fig $3 \mathrm{~A}, \mathrm{~B}$ ). One day after injection, HC induced the well
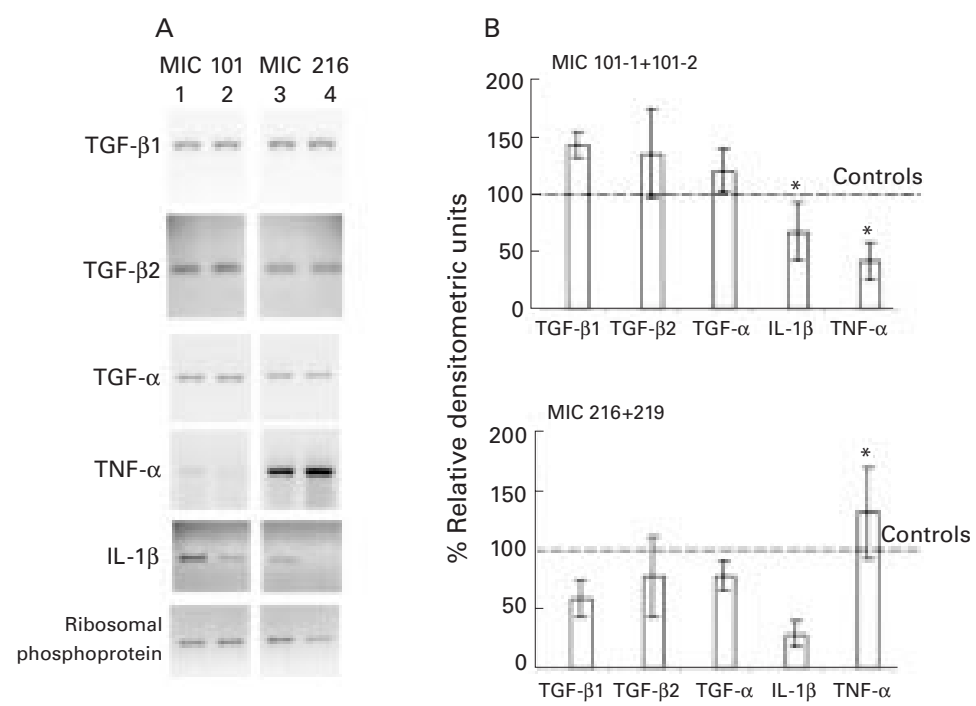

Figure 4 Effect of DX on expression of cytokines by subepithelial myofibroblast cell lines. (A) Representative RT-PCR analysis of transforming growth factor $\beta 1$ and $\beta 2$ (TGF- $\beta 1$, $T G F-\beta 2)$, transforming growth factor a (TGF-a), tumour necrosis factor a (TNF- $\alpha$ ), interleukin $1 \beta(I L-1 \beta)$, and ribosomal protein transcripts extracted from myofibroblasts cloned from the jejunum (MIC 101-1; lanes 1 and 2) and ileum (MIC 216; lanes 3 and 4). Myofibroblastic cells were cultured for two days in the basic medium (lanes 1 and 3) and in the presence of $8 \times 10^{-7} M D X$ (lanes 2 and 4). (B) Densitometric analysis of $T G F-\beta 1, T G F-\beta 2, T G F-\alpha, I L-1 \beta$, and TNF- $\alpha$ bands (normalised to values of ribosomal protein used as internal control): mean of values obtained from the experiments performed on the two jejunal (MIC 101-1 and 101-2) or the two ileal (MIC 216 and 219) cell lines which gave identical results. Results are illustrated in the DX treated cultures as percentages of the corresponding controls. ${ }^{\star} p<0.05$ compared with controls (unpaired t test). known appearance of SI mRNA. HC injection also resulted in a significant decrease in expression of TGF- $\beta 1$, TGF- $\beta 2$, and IL- $1 \beta$. No modifications in the amount of TGF- $\alpha$ or TNF- $\alpha$ mRNAs were observed.

EFFECT OF DX ON EXPRESSION OF CYTOKINES BY SMALL INTESTINAL MYOFIBROBLAST CELL LINES To test if the variations in cytokine expression observed in vivo under the influence of $\mathrm{HC}$ injection could be attributed, at least partly, to an action on the subepithelial mesenchymal cells, we studied in vitro the effect of GC on expression of the cytokines by subepithelial myofibroblast clonal cell lines. ${ }^{10}$ The cell lines analysed were established from the proximal jejunum (MIC 101-1 and 101-2) and distal ileum (MIC 216 and 219); all expressed the five cytokines studied (fig 4). The results showed that, in contrast with the effects of HC observed in vivo, DX did not significantly modify expression of the TGF- $\beta$ isoforms in the ileal and jejunal cell lines. However, DX decreased expression of IL- $1 \beta$ in vitro, similar to its effects in vivo. Interestingly, the level of TNF- $\alpha$ mRNA was maximal in myofibroblasts of ileal origin (fig 4A) and DX modulated its expression differentially according to the proximo-distal axis: decrease or increase, respectively, in the jejunal and ileal clones (fig 4B).

\section{Discussion}

In the present study, we focused on expression of mucosal cytokines during postnatal maturation of the small intestinal mucosa and on regulation of their expression by circulating hormones. The results indicate differential developmental patterns in the expression of cytokines in the intestinal mucosa at weaning: the decrease in TGF- $\beta 1$, TGF- $\beta 2$, and IL- $1 \beta$ mRNAs and increase in TNF- $\alpha$ mRNA coincided with the onset of SI expression and segregation of SI transcripts at the apical part of the enterocyte. In vivo, injection of $\mathrm{HC}$ induced precocious induction of SI and, in parallel, a decrease in the expression of TGF- $\beta 1$ and $\beta 2$, and IL- $1 \beta$. In vitro, DX also inhibited IL- $1 \beta$ but did not affect the TGF- $\beta$ isoforms expressed by subepithelial myofibroblast cells. No variations in $\mathrm{TNF}-\alpha$ were seen after $\mathrm{HC}$ treatment in vivo but $\mathrm{DX}$ differentially regulated $\mathrm{TNF}-\alpha$ in the jejunal and ileal myofibroblast cell lines.

TGF- $\beta$ isoforms and other members of the TGF- $\beta$ family are known to be involved in early epithelial-mesenchymal cell interaction dependent morphogenesis in several organs. ${ }^{30-32}$ In this study we showed that transcripts of TGF- $\beta 1$ and $\beta 2$ isoforms were expressed in the postnatal intestinal mucosa and that they decreased during the third week of life to reach low levels in the adult organ. Contrasting with our observations on detection of mRNA in the whole mucosa which comprises various cell types (epithelial, immune, muscular, and fibroblastic cells), Penttila and colleagues ${ }^{33}$ reported an increase in TGF- $\beta$ expression in epithelial cells at weaning. Other authors showed that at this stage only the most apical 
villus enterocytes expressed TGF- $\beta 1,{ }^{13}$ that no transcripts were found in the fibroblastic cells of healthy mucosa ${ }^{33} 34$ but that they were increased in the lamina propria cells in inflamed mucosa. ${ }^{34}$ Similarly, the fibroblastic cell lines derived from postnatal intestines used in the present work expressed TGF- $\beta 1$ and $\beta 2 .^{10}$ Thus in both postnatal and inflamed intestine, TGF- $\beta 1$ may be involved in tissue remodelling. As an example, mesenchymally derived TGF- $\beta 1$ induces intestinal epithelial cells to form glands in cocultures. ${ }^{12}$ It is also noteworthy that TGF- $\beta$ isoforms inhibit the proliferation of intestinal epithelial cells ${ }^{12-14} 35$ and stimulate apoptosis of cells localised at the villus tip. ${ }^{36}$

The increase in circulating GC during the third week of postnatal life in rodents is associated with the final step of intestinal maturation, namely the onset of the specialised functions necessary to digest the adult diet and in particular induction of expression of SI in the small intestine. These changes are concomitant with an increased turnover rate of the epithelial cells resulting in the crypt-villus homeostasis characteristic of the mature organ. Interestingly, our data indicated an inverse correlation between, on the one hand the physiological or experimental increase in GC concentration paralleled with induction of SI, and on the other, a decrease in expression of TGF- $\beta 1$ and $\beta 2$ mRNAs. This is in agreement with the reduction in latent TGF- $\beta$ production by normal intestinal epithelial cells (IEC6 cell line) after addition of hydrocortisone. ${ }^{37}$ Thus TGF- $\beta$ isoforms may be implicated in the morphological and functional maturation of the gut during development and their decrease around weaning, at least partly controlled by GC, may allow the onset of the adult crypt-villus cell turnover in parallel with the final steps of functional maturation.

Our results showed that the proinflammatory cytokine IL- $1 \beta$ mRNA is expressed in the intestinal mucosa at all stages, the highest expression being observed in the proximal jejunum. In vivo, IL-1 $\beta$ has been localised exclusively in lamina propria mononuclear cells and in Peyer's patches, ${ }^{26}{ }^{38}$ this cytokine being expressed in the epithelial cells only in pathological conditions (in tumour cell lines and acute experimental colitis ${ }^{39}{ }^{40}$ ). We found that IL-1 $\beta$ was also expressed in the cultured subepithelial myofibroblasts with a decreasing gradient from the jejunum to the colon. The developmental pattern of IL- $1 \beta$ in the small intestinal mucosa may therefore reflect its expression in both mononuclear cells and connective tissue fibroblasts. In common with TGF- $\beta 1$ and TGF- $\beta 2$, IL- $1 \beta$ expression decreased towards weaning, at least in the proximal jejunum. Our data also showed that IL-1 $\beta$ expression was decreased in the jejunum by HC treatment and in intestinal myofibroblasts by addition in vitro of $\mathrm{DX}$, indicating that this cytokine is negatively controlled by GC. Interestingly, a negative regulatory region containing a GC response element has recently been identified in the IL- $1 \beta$ gene. ${ }^{41}$ As intestinal epithelial cells express IL-1 $\beta$ receptors, ${ }^{42}{ }^{43}$ the mesenchymally derived IL-1 $\beta$ may play a role in the functional development of the gut, suggested previously by Mengheri and colleagues. ${ }^{26}$ Also, its expression could be directly downregulated as a result of the physiological increase in plasma GC concomitant with the final step of intestinal maturation.

TNF- $\alpha$, another important proinflammatory cytokine, is present in the small intestinal mucosa during postnatal development. TNF- $\alpha$ has previously been localised in inflammatory cells, fibroblasts, and murine Paneth cells. ${ }^{44}$ In common with IL- $1 \beta, \mathrm{TNF}-\alpha$ has been found in the intestinal epithelium only in pathological conditions such as Crohn's disease ${ }^{45}$ and intestinal inflammation induced in IL-2 knockout mice. ${ }^{46}$ Also, $\mathrm{TNF}-\alpha$ is induced in colonic epithelial cancer cell lines after bacterial challenge. ${ }^{39} 4748$ Our data showed that TNF- $\alpha$ was expressed in normal rat myofibroblasts with an increasing proximo-distal gradient. The fact that DX regulates TNF- $\alpha$ expression negatively in cultured myofibroblasts isolated from the jejunum and positively in myofibroblasts of ileal origin is interesting and should be analysed further. Related to the increase in TNF- $\alpha$ expression in the proximal jejunum at weaning when SI is induced, recent data have shown that TNF- $\alpha$ mediates, in a concentration dependent manner, the increase in the biosynthesis of SI in the human epithelial cell line Caco $2 .{ }^{25}$ However, as TNF- $\alpha$ injected in vivo before weaning has no effect on sucrase activity ${ }^{49}$ this cytokine does not seem to be implicated in the onset of SI expression but rather in its subsequent increase. Accordingly, expression of TNF- $\alpha$ in the proximal jejunum was not modified in vivo by HC. Finally, TNF- $\alpha$ may also be implicated in the changes in crypt cell proliferation which occur at weaning, as activation of the local immune system occurs at this stage and as a stimulatory effect on IEC- 6 cell growth has been observed..$^{50}$

The absence of significant variations in the expression and regulation of TGF- $\alpha$ mRNA during postnatal development is in accordance with the presence of the protein at similar concentrations in the suckling and adult rat ${ }^{15}$ and suggests that this growth factor is not implicated in the major changes that occur at weaning. However, EGF-R knockout mice suffer from impaired epithelial development ${ }^{18}$ and EGF, which binds to the same receptors as TGF- $\alpha$, can induce expression of SI in vivo. ${ }^{19}$ Thus one may assume that EGF is involved in differentiation in the small intestine of suckling rats $^{51}$ whereas TGF- $\alpha$ may only be implicated in basal regulation of the rate of cellular proliferation.

In conclusion, our results showed that intestinal maturation assessed by intense accumulation of SI mRNA in the apical part of the enterocyte at weaning, was concomitant with a decrease in TGF- $\beta$ isoforms and IL- $1 \beta$ expression and an increase in $\mathrm{TNF}-\alpha$. This suggests that the relative concentrations of these cytokines may be crucial in the processes of morphological and functional postnatal maturation and in the subsequent homeostasis of the small intestine. This conclusion is further 
corroborated by the fact that the decrease in TGF- $\beta$ isoforms and IL- $1 \beta$ may be controlled by circulating GC during the preweaning period. Finally, our data also showed that mucosal inflammatory peptides and growth factors were differentially expressed and responsive to GC in subepithelial myofibroblasts confirming that these cells are also implicated in the functional maturation and homeostasis of the epithelium. The authors wish to express their gratitude to Dr M. Babyatsky
and Professor D K Podolsky (MGH, Harvard Medical School, Boston, Massachusetts, USA) for initiation to the in situ Boston, Massachusetts, USA) for initiation to the in situ
hybridisation technique and Dr S J Henning (Department of hybridisation technique and Dr S J Henning (Department of Pediatrics, Baylor College of Medicine, Houston, Texas, USA)
for the generous gift of the rat sucrase-isomaltase probe. We for the generous gift of the rat sucrase-isomaltase probe. We gratefully acknowledge Dr J N Freund and O Lefebvre for
advice and help in this work. We thank Mrs E Martin and C advice and help in this work. We thank Mrs E Martin and C Arnold for their expert technical support, and Mrs L Mathern
and I Gillot for the high quality of the illustrations and excellent and I Gillot for the high quality of the illustrations and excellent preparation of the manuscript. Financial support was from ticals (Danemark).

1 Fiocchi C. Intestinal inflammation: a complex interplay of immune and non immune cell interactions. Am f Physiol 1997;273:G769-75.

2 Kagnoff MF, Eckmann L, Yang SK, et al. Intestinal epithelial cells: an integral component of the mucosal immune system. In: Kagnoff MF, Kiyono H, eds. Essentials of mucosal in: Kagnoff MF, Kiyono $\mathrm{H}$, eds. Essentials of 1 im

3 Smith RS, Smith TJ, Blieden TM, et al. Fibroblasts as sentinel cells. Synthesis of chemokines and regulation of inflammation. Am f Pathol 1997;151:317-22.

4 Birchmeier C, Birchmeier W. Molecular aspects of mesenchymal-epithelial interactions. Annu Rev Cell Biol 1993:9.511-40.

5 Kedinger M, Freund JN, Launay JF, et al. Cell interactions hrough basement membrane in intestinal developmen and differentiation. In: Sanderson IR, Walker WA, eds. Development of the gastrointestinal tract. BC Decker Inc., 1999:83-102.

6 Yasugi S. Role of epithelial-mesenchymal interactions in differentiation of epithelium of vertebrate digestive organs. Dev Growth Differ 1993;35:1-9.

7 Plateroti M, Freund J-N, Leberquier C, et al. Mesenchymemediated effects of retinoic acid during rat intestinal development. F Cell Sci 1997;110:1227-38.

8 Simo P, Simon-Assmann P, Arnold C, et al. Mesenchymemediated effect of dexamethasone on laminin in cocultures of embryonic gut epithelial cells and mesenchyme-derived of embryonic gut epithelial cells an

9 Göke, M, Kanai M, Podolsky DK. Intestinal fibroblasts regulate intestinal epithelial cell proliferation via hepatoregulate intestinal epithelial cell proliferation via hep
cyte growth factor. Am 7 Physiol 1998;274:G809-18.

10 Plateroti M, Rubin DC, Duluc I, et al. Subepithelial fibroblast cell lines from different levels of gut axis display regional characteristics. Am f Physiol 1998;274:G945-54.

11 Fritsch C, Orian-Rousseau V, Lefebvre O, et al. Characterization of human intestinal stromal cell lines: response to cytokines and interactions with epithelial cells. Exp Cell Res 1999;248:391-406

12 Halttunen T, Marttinen A, Rantala I, et al. Fibroblasts and transforming growth factor $\beta$ induce organization and differentiation of T84 human epithelial cells. Gastroenterology 1996;111:1252-62.

13 Barnard JA, Beauchamp RD, Coffey RJ et al. Regulation of intestinal cell growth by transforming growth factor type $\beta$. Proc Natl Acad Sci USA 1989;86:1578-82

14 Kurokowa M, Lynch K, Podolsky DK. Effects of growth factors on an intestinal epithelial cell line: Transforming growth factor $\beta$ inhibits proliferation and stimulates differgrowth factor $\beta$ inhibits proliferation and stimulates differ-

15 Dvorak B, Holubec H, LeBouton AV, et al. Epidermal growth factor and transforming growth factor- $\alpha$ mRNA in rat small intestine: in situ hybridization study. Febs Let 1994b;352:291-5.

16 Dvorak B, Koldovsky O. The presence of transforming growth factor- $\alpha$ in the suckling rat small intestine and pancreas and the absence in rat milk. Pediatr Res 1994;35:348-53.

17 Hormi K, Onolfo JP, Gres L, Lebraud V, Lehy T. Developmental expression of transforming growth factor-alpha in the upper digestive tract and pancreas of the rat. Regul Pept 1995;55:67-77.

18 Miettinen PJ, Berger JE, Meneses J, et al. Epithelial immaturity and multiorgan failure in mice lacking epidermal
growth factor receptor. Nature 1995;376:337-41.

19 Nsi Emvo E, Raul F, Koch B, et al. Sucrase-isomaltase gene expression in suckling rat intestine: hormonal, dietary, and growth factor control. F Pediatr Gastroenterol Nutr 1996;23: 262-9.

20 Podolsky DK. Regulation of intestinal epithelial proliferation: a few answers, many questions. Am $\mathcal{F}$ Physiol 1993;264:G179-86.

21 Thompson FM, Mayrhofer G, Cummins AG. Dependence of epithelial growth of the small intestine on T-cell activation during weaning in the rat. Gastroenterology 1996 111:37-44
22 Ahuja SS, Shrivastav S, Danielpour D, et al. Regulation of transforming growth factor- $\beta 1$ and its receptor by cyclosporine in human T lymphocytes. Transplantation 1995; 60:718-23.

23 Cummins AG, Labrooy JT, Shearman DJC. The effect of cyclosporin A in delaying maturation of the small intestine during weaning in the rat. Clin Exp Immunol 1989;75:451-6. 24 Neumann B, Luz A, Pfeffer K, et al. Defective Peyer's patch organogenesis in mice lacking the $55-\mathrm{kD}$ receptor for tumor necrosis factor. 7 Exp Med 1996;184:259-64.

25 Ziambaras T, Rubin DC, Perlmutter DH. Regulation of sucrase-isomaltase gene expression $\mathrm{n}$ human intestinal cells by inflammatory cytokines. F Biol Chem 1996;2:1237-42.

26 Mengheri E, Ciapponi L, Vignolini F, et al. Cytokine gene expression in intestine of rat during the postnatal development period: increased IL-1 expression at weaning. Life Sci 1996;59:1227-36.

27 Laurent-Huck FM, Egles C, Kienlen P, et al. Expression of the c-ets 1 gene in the hypothalamus and pituitary during at development. Dev Brain Res 1996;97:107-17.

28 Laurent-Huck FM, Felix JM. Measurement of oxytocin and vasopressin gene expression by in situ hybridization. Methods Neurosici 1991;5:159-82.

29 Chandrasena G, Snitha I, Lau C, et al. Expression of sucrase-isomaltase mRNA along the villus-crypt axis in the rat small intestine. Cell Mol Biol 1992;38:243-54

30 Mahida YR, Ciacci C, Podolsky DK. Peptide growth factors: role in epithelial lamina propria cell interactions. Ann NY Acad Sci 1992;664:148-56.

31 Roberts DJ, Johnson RL, Burke AC, et al. Sonic hedgehog is an endodermal signal inducing Bmp-4 and Hox genes during induction and regionalization of the chick hindgut. Development 1995;121:3163-74.

32 Thesleff I, Sahberg C. Growth factors as inductive signals regulating tooth morphogenesis. Cell Dev Biol 1996;7:18593.

33 Penttila IA, van Spriel AB, Zhang MF, et al. Transforming growth factor-beta levels in maternal milk and expression in postnatal rat duodenum and ileum. Pediatr Res 1998;44: 524-31.

34 Babyatsky MW, Rossiter G, Podolsky DK. Expression of transforming growth factors $\alpha$ and $\beta$ in colonic mucosa in inflammatory bowel disease. Gastroenterology 1996;110: 975-84.

35 Ko TC, Beauchamp RD, Townsend CM, et al. Transforming growth factor- $\beta$ inhibits rat intestinal cell growth by regulating cell cycle specific gene expression. Am f Surg 1994;167:14-20.

36 Jones BA, Gores GJ. Physiology and pathophysiology of apoptosis in epithelial cells of the liver, pancreas, and intestine. Am f Physiol 1997;273:G1174-88.

37 Quaroni A, Tian JQ, Goke $M$, et al. Glucocorticoids have pleiotropic effects on small intestinal crypt cells. Am $\mathcal{F}$ Physiol 1999;277:G1027-40.

38 Youngman KR, Simon PL, West GA, et al. Localization of intestinal interleukin 1 activity and protein and gene expression to lamina propria cells. Gastroenterology 1993; 104:749-58.

39 Eckmann L, Yung HC, Schurer-Maly C, et al. Differential cytokine expression by human intestinal epithelial cells lines: regulated expression of interleukin 8. Gastroenterology

40 Radema SA, Van Deventer JHS, Cerami A. Interleukin $1 \beta$ is expressed predominantly by enterocytes in experimental colitis. Gastroenterology 1991;100:1180-6.

1 Zhang G, Zhang L, Duff GW. A negative regulatory region containing a glucocorticosteroid response element (nGRE) in the human interleukin-1 $\beta$ gene DNA. Cell Biol 1997;16: $145-52$

42 McGee DW, Vitkus SJ, Lee P. The effect of cytokine stimulation on IL-1 receptor mRNA expression by intestinal epithelial cells. Cell Immunol 1996;168:276-80.

43 Molmenti EP, Ziambaras T, Perlmutter DH. Evidence for acute phase response in human intestinal epithelial cells. $\mathcal{F}$ Biol Chem 1993;268:14116-24.

44 Keshavs S, Lawson L, Chung LP, et al. Tumor necrosis factor mRNA localized to Paneth cells of normal murine intestinal epithelium by in situ hybridization. $\mathcal{F}$ Exp Med 1990;171:327-32.

45 Beil WJ, Weller PF, Peppercorn MA, et al. Ultrastructural immunogold localization of subcellular sites of TNFa in colonic Crohn's disease. F Leukoc Biol 1995;58:284-98.

46 Autenrieth IB, Bucheler N, Bohn E, et al. Cytokine mRNA expression in intestinal tissue of interleukin-2 deficient mice with bowel inflammation. Gut 1997;41:793-800.

47 Meijssen MA, Brandwein SL, Reinecker HC, et al. Alteration of gene expression by intestinal epithelial cells precedes colitis in interleukin-2-deficient mice. $\mathrm{Am}$ Physiol 1998;274:472-9.

48 Michalsky MP, Deitch EA, Ding J, et al. Interleukin-6 and tumor necrosis factor production in an enterocyte model (Caco-2) during exposure to Escherichia coli. Shock 1997; 7:139-46.

49 Kaouass M, Deloyer P, Gouders I, et al. Role of interleukin$1 \beta$, interleukin-6, and $\mathrm{TNF} \alpha$ in intestinal maturation induced by dietary spermine in rats. Endocrine 1997;6:18794.

50 Dionne S, D'Agata ID, Ruemmele FM, et al. Tyrosine kinase and MAPK inhibition of TNF-alpha- and EGFstimulated IEC-6 cell growth. Biochem Biophys Res Comm 1998;242:146-50

1 Schaudies RP, Grimes J, Davis D, et al. EGF content in the gastrointestinal tract of rats: effect of age and fasting/ feeding. Am F Physiol, 1989;256:G856-61. 